\title{
Zmienność przepływów niżówkowych w wybranych zlewniach pogórskich i beskidzkich w latach 1988-2017 \\ Variability of low flow in Polish Carpathians (foothills and Beskidy Mountains) catchments in the period 1988-2017
}

\author{
Witold Bochenek (D) Małgorzata Kijowska-Strugała \\ Instytut Geografii i Przestrzennego Zagospodarowania im. S. Leszczyckiego PAN \\ Stacja Badawcza w Szymbarku \\ 38-311 Szymbark 430 \\ witold.bochenek@zg.pan.krakow.pl•mkijowska@zg.pan.krakow.pl
}

Zarys treści. Wieloletnia analiza (1988-2017) przepływów wody w dwóch zlewniach pogórskich (Skawinka i Stobnica) i dwóch beskidzkich (Soła i Osława) w polskich Karpatach umożliwiła rozpoznanie czasu trwania przepływów niźówkowych i niedoboru odpływu w nawiązaniu do zmian pokrycia terenu i użytkowania ziemi. W wybranych zlewniach, w okresie 30 lat odnotowano zmniejszenie powierzchni gruntów ornych oraz wzrost powierzchni użytków zielonych, lasów oraz obszarów zabudowanych. Stwierdzono większą podatność na wystąpienie niżówki całkowitej w zlewniach beskidzkich, w których czas trwania przepływów niżówkowych i niedobór odpływu był większy niż w zlewniach pogórskich. Równocześnie zlewnie beskidzkie są mniej podatne na wystąpienie niżówki głębokiej, z powodu większej lesistości i przepuszczalności pokryw glebowo-zwietrzelinowych. W ujęciu regionalnym stwierdzono zwiększający się czas trwania przepływów niżówkowych i niedobór odpływu w zlewniach położonych we wschodniej części badanego obszaru (zlewnie Stobnicy i Osławy), spowodowane nasileniem się w tym obszarze kontynentalnych cech klimatu.

Słowa kluczowe: przepływ niżówkowy, metoda odcięcia, wskaźnik suchości klimatu, zmiany pokrycia terenu i użytkowania ziemi, polskie Karpaty.

Keywords: low flow, threshold level method, aridity index, land use and land cover changes, Polish Carpathians.

\section{Wstęp}

Obserwowane w ostatnich kilkudziesięcioleciach globalne zmiany klimatyczne, przejawiają się przede wszystkim wzrostem temperatury powietrza (Stocker et al., 2013; Damborská et al., 2016; IPCC, 2018), który wypływa na zmiany w obiegu wody (Huntington et al., 2006), w tym zwiększenie parowania terenowego (Douville et al., 2013), zmniejszenie wilgotności gleb (Sheffield i Wood, 2008) i ograniczenie dopływu wody do cieków, których końcowym efektem jest niżówka rzeczna (Clausen i Pearson, 1995; Shabalova et al., 2003; Dai, 2011, 2013; Spinoni et al., 2013). Seneviratne (2012) wskazuje, że większą uwagę powinno się położyć na czasoprzestrzenne rozpoznanie rozwoju suszy hydrologicznej, której skutkiem w okresie letnim jest m.in. wzrost temperatury wody i niskie stężenie tlenu rozpuszczonego (Caruso, 2002). Deficyt dostępnej wody wpływa na konieczność ograni- 
czenia jej poboru dla potrzeb gospodarczych (w tym rolniczych) i komunalnych (Lopez-Nicolas et al., 2017).

Obszar polskich Karpat charakteryzuje się specyficznymi warunkami formowania się niżówek. Badania Dynowskiej (1971) przeprowadzone na obszarze Karpat Zachodnich wskazały, że najgłębsze niżówki występują w rzekach Beskidu Niskiego i Pogórza Karpackiego. Analizę przebiegu i czasu trwania niżówek w górnych odcinkach Soły, Skawy, Raby i Dunajca przedstawił Punzet (1996), zwracając uwagę na specyfikę odpływu niżówkowego ze zlewni Dunajca, spowodowaną względnie wysoką objętością wody odpływającej z tej zlewni podczas niżówek.

Na wieloletnie tendencje długości i intensywności niżówek (niedoboru odpływu) wpływają m.in. zmieniające się warunki klimatyczne (temperatura powietrza, usłonecznienie, sumy opadów i ich rozkład w czasie) oraz zmiany pokrycia terenu i użytkowania ziemi (Dai, 2011). Według Hundecha i Bardossy (2004) wpływ pokrycia terenu na mechanizm odpływu wody nie jest do końca rozpoznany, głównie ze względu na niejednorodność użytkowania i równoczesny wpływu klimatu. W polskich Karpatach Zachodnich w ciągu ostatnich 30 lat obserwowano zmiany pokrycia terenu i użytkowania ziemi, związane z transformacją gospodarczą w kraju po 1989 r., a także z przystąpieniem Polski do Unii Europejskiej w 2004 r. Dotyczyły one głównie przejścia z użytkowania gruntów ornych w kierunku obszarów odłogowanych i łąkowych (Kulikowski, 2001; Kijowska-Strugała, 2019) oraz wzrostu zalesienia (Kozak, 2005). Las odgrywa istotną rolę w regulacji naturalnego obiegu wody i wywiera wpływ na zdolności retencyjne zlewni. Badania Bagley et al. (2014) wykazały, że wzrost zalesienia zwiększa retencyjność, natomiast deforestacja przyspiesza odpływ wody. Istotne znacznie ma również notowany w zlewniach karpackich wzrost powierzchni zabudowanych i rozbudowa infrastruktury (utwardzenie dróg, placów, drenaż linijny itp.) (Kroczak et al., 2016).

Głównym celem artykułu jest rozpoznanie czasu trwania i wielkości niedoboru odpływu podczas przepływów spełniających kryteria niżówki całkowitej i niżówki głębokiej w czterech zlewniach rzecznych (pogórskich i beskidzkich) w Karpatach Zachodnich w okresie 30 lat (1988-2017) oraz ocena wrażliwości zasobów wodnych na zmiany pokrycia terenu i użytkowania ziemi.

\section{Materiały i metody badań}

Do badań wybrano dwie zlewnie pogórskie: Skawinki (przekrój Radziszów) i Stobnicy (przekrój Godowa) oraz dwie zlewnie beskidzkie: Soły (przekrój Rajcza) i Osławy (przekrój Szczawne), o podobnej powierzchni - od 294 do 324 km² (ryc. 1, tab. 1). Dobór zlewni związany był ze zróżnicowanym: reżimem odpływu, spowodowanym położeniem badanych obszarów w różnych częściach Karpat Zachodnich (Ziemońska, 1973), udziałem i kierunkami zmian pokrycia terenu i użytkowania ziemi w latach 1988-2017 oraz dostępnością i kompletnością danych średnich dobowych przepływów wody.

Średnie nachylenie zlewni pogórskich było o $5^{\circ}$ niższe niż zlewni beskidzkich, a średnia wysokość niższa o 374 m. Występowanie na obszarze Karpat Zachodnich zlewni pogórskich i beskidzkich jest uwarunkowane rzeźbą terenu, będącą skutkiem budowy geologicznej (Starkel, 1972). W pogórskiej części omawianego obszaru występują serie skalne z dominacją łupków, mniej odporne na działanie procesów egzogenicznych. W podło- 

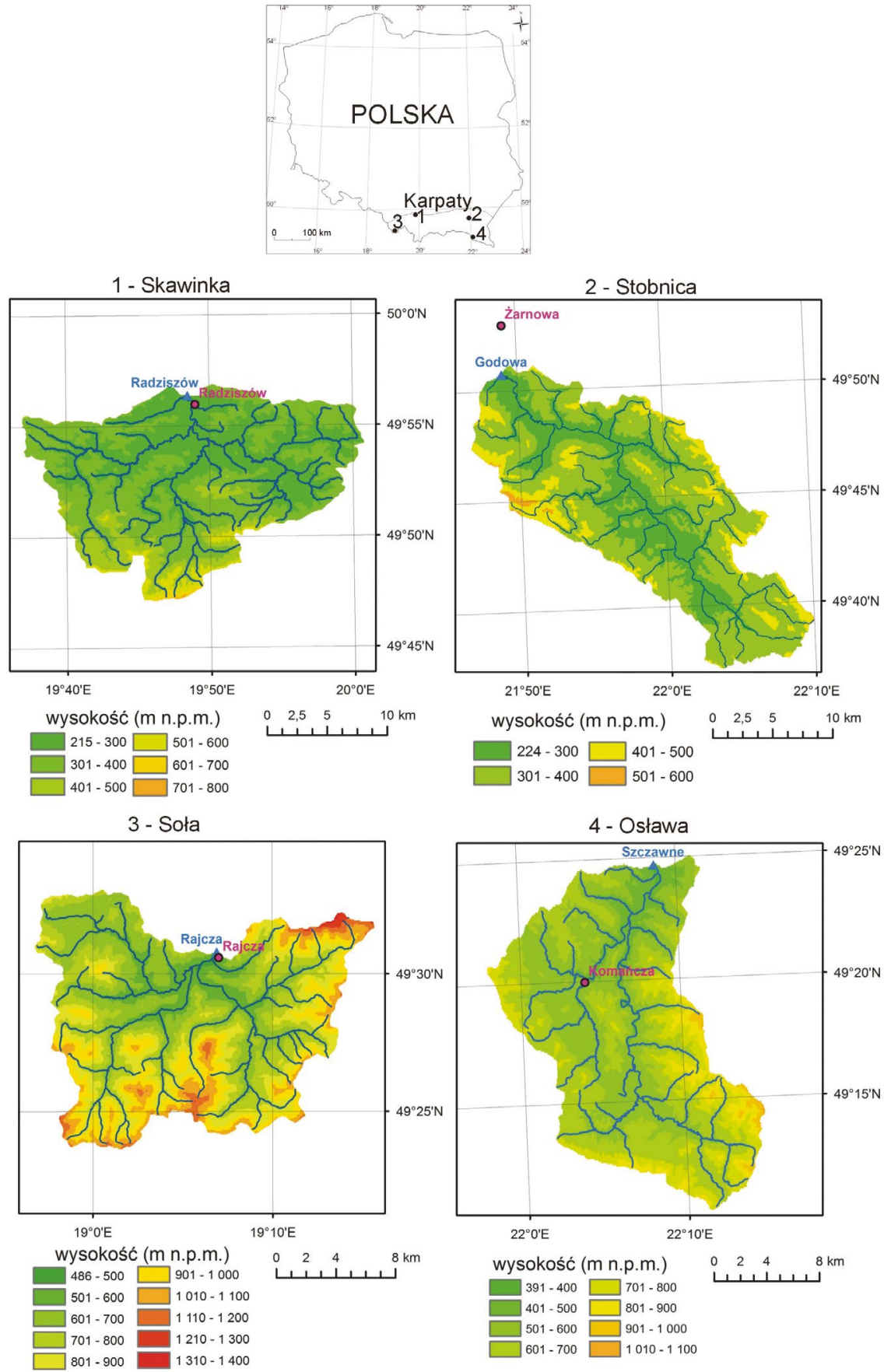

Ryc. 1. Lokalizacja zlewni badawczych w polskich Karpatach (niebieski trójkąt - lokalizacja wodowskazu, czerwone koło - lokalizacja deszczomierza) Locations of the study catchments in the Polish Carpathians (blue triangle - water gauge, red circle - rain gauge) 
Tabela 1. Podstawowe parametry analizowanych zlewni Key parameters of the catchments analysed

\begin{tabular}{|c|c|c|c|c|c|c|}
\hline \multirow[t]{2}{*}{ Rzeka } & \multirow{2}{*}{$\begin{array}{c}\text { Lokalizacja } \\
\text { wodowskazu }\end{array}$} & $\begin{array}{c}\text { Powierzchnia } \\
\text { zlewni }\end{array}$ & $\begin{array}{l}\text { Średnia } \\
\text { wysokość }\end{array}$ & $\begin{array}{c}\text { Średnie } \\
\text { nachylenie }\end{array}$ & $\begin{array}{c}\text { Gęstość sieci } \\
\text { rzecznej }\end{array}$ & \multirow{2}{*}{$\begin{array}{c}\text { Lokalizacja } \\
\text { deszczomierza }\end{array}$} \\
\hline & & $\mathrm{km}^{2}$ & m n.p.m. & 。 & $\mathrm{km} \mathrm{km}^{-2}$ & \\
\hline Skawinka & Radziszów & 317 & 339 & 6,66 & 2,62 & Radziszów \\
\hline Stobnica & Godowa & 324 & 346 & 7,04 & 3,01 & Żarnowa \\
\hline Soła & Rajcza & 294 & 798 & 13,26 & 3,07 & Rajcza \\
\hline Osława & Szczawne & 302 & 636 & 9,82 & 2,78 & Komańcza \\
\hline
\end{tabular}

żu geologicznym zlewni pogórskich występują w przeważającej części utwory jednostki śląskiej wieku kredowo-paleogeńskiego, w której większy udział mają łupki w stosunku do piaskowców, w porównaniu z seriami: magurską i dukielską. Na niewielkich fragmentach powierzchni zlewni występują osady mioceńskie oraz czwartorzędowe płaty lessowe.

Beskidzka część Karpat Zachodnich, w której partie szczytowe przekraczają 1000 m n.p.m., zbudowana jest z serii skalnych z dominacją piaskowców, odpornych na procesy erozyjne i denudacyjne. Podłoże geologiczne zlewni Soły stanowią w przeważającej części utwory płaszczowiny magurskiej, zbudowane z piaskowców, łupków, zlepieńców, mułowców i iłowców wieku od kredy do oligocenu (Unrug, 1969). Utwory budujące serię dukielską (piaskowce, łupki, mułowce, iłowce, margle) występują w podłożu zlewni Osławy (Żytko et al., 1973).

Analizę przepływów niżówkowych przeprowadzono dla 30 lat hydrologicznych (01.11.1988-31.10.2017). Dla każdej z badanych zlewni wybrano referencyjny posterunek opadowy (ryc. 1, tab. 1), z którego dane służyły do obliczeń wybranych wartości względnych (m.in. współczynnika odpływu). Obliczenia wykonano na podstawie danych z posterunków opadowych i wodowskazowych Instytutu Meteorologii i Gospodarki Wodnej Państwowego Instytutu Badawczego (IMGW, 2018). Jako dane źródłowe pobrano średnie dobowe wartości natężenia przepływu i miesięczne sumy opadów atmosferycznych.

Dysponując 30-letnimi seriami pomiarów opadu i odpływu, zbadano homogeniczność danych, wykorzystując w tym celu test Petitta. Serie rocznych sum opadu na referencyjnych posterunkach opadowych oraz odpływu w profilach wodowskazowych w badanym okresie były jednorodne na poziomie $p>0,05$.

Do sporządzenia krzywych hipsometrycznych i rozkładów nachyleń wykorzystano dane z Shuttle Radar Topography Mission (SRTM, USGS, 2017). Dane dotyczące pokrycia terenu i użytkowania ziemi zostały pobrane ze strony Europejskiej Agencji Środowiska (European..., 2019). Wykorzystano dane z lat: 1990, 2006 oraz 2018. Warstwy wektorowe klas pokrycia terenu zostały sporządzone na podstawie danych ze zobrazowań misji: Landsat 4/5 (CLC 1990), IRS i SPOT-4, (CLC 2006), Sentinel 2 i Landsat 8 (CLC 2018).

W literaturze brakuje jednoznacznej definicji niżówki, a założenia służące wyróżnieniu okresów niżówkowych są subiektywne i wymagają zawsze oddzielnej analizy (Zielińska, 1964; Ozga-Zielińska i Brzeziński, 1994). Kluczowe jest wyznaczenie poziomu odcięcia, czyli wartości progowej oddzielającej od siebie okresy nadwyżek i niedoborów wody. Jedną z metod wyznaczenia tego poziomu jest obliczenie średniego odchylenie $\left(S_{Q}\right)$ od średniego przepływu $\left(Q_{s r}\right)$ pomnożonego przez obieralną miarę wartości poziomu odcięcia 
wynikającą z potrzeb zagwarantowania minimalnego poboru wody przez użytkowników (Yevjevich, 1964). Innym kryterium delimitacji okresów niżówkowych jest górna granica stanów (lub przepływów) niskich WNW (WNQ) (Ozga-Zielińska i Brzeziński, 1994). Metoda ta jest jednak oparta na jednej, ekstremalnej wartości (WNQ) obliczonej z ekstremów rocznych (NQ) z poszczególnych lat oraz średniej (SNQ) obliczonej z wartości ekstremalnych rocznych. Była ona powszechnie stosowana w polskiej literaturze hydrologicznej (Lambor, 1971; Ozga-Zielińska i Brzeziński, 1997; Fal, 2007; Tomaszewski, 2007; Kaznowska i Banasik, 2009; Kaznowska et al., 2015; Bochenek, 2020).

W ostatnim okresie do wyznaczania progowych wartości przepływów niżówkowych wykorzystywana jest metoda krzywej czasów trwania przepływów wraz z wyższymi (Hisdal et al., 2004), zastosowana w licznych opracowaniach hydrologicznych (Tallaksen et al., 2009; Fleig et al., 2011; Tomaszewski, 2012; Van Loon i Laaha, 2015; Wanders et al., 2015; Bochenek, 2017; Marszelewski et al., 2017; Bochenek i Kijowska-Strugała, 2018). Polega ona na przyjęciu progowej wartości przepływu dla niżówki, odpowiadającej wymaganemu percentylowi w uszeregowanym nierosnąco zbiorze średnich dobowych przepływów w badanym okresie. Pierwotnie Hisdal et al. (2004) zaproponowali przyjęcie natężenia przepływu odpowiadającego 70. percentylowi jako progowej wartości niżówki całkowitej i przepływu odpowiadającemu 95. percentylowi jako progowi niżówki głębokiej. Autorzy innych opracowań modyfikowali tę metodę, przyjmując jako progi niżówki inne wartości percentyli. Wanders et al. (2015) w badaniach niżówek na świecie w XXI w. przyjęli jako próg niżówki 90. percentyl. Tallksen et al. (2009) do „konstrukcji” krzywej czasu trwania przepływu wykorzystali dobowy przepływ, obliczony jako średnia ruchoma z 30-dniowego okresu. Na podstawie tak skonstruowanej krzywej wyznaczyli poziom odcięcia niżówki odpowiadający 80. percentylowi.

W niniejszym opracowaniu przyjęto, postulowane przez Hisdal et al. (2004), wartości percentyli 70 i 95 odpowiadające odpowiednio niżówce całkowitej i głębokiej. Zakres natężenia przepływu między percentylami 70 i 95 odpowiada przepływowi niżówki płytkiej. Ze względu na zróżnicowanie w ciągu roku wpływu warunków klimatycznych (głównie wielkości parowania terenowego) na kształtowanie przebiegu i wielkości przepływów niżówkowych, delimitację okresów niżówkowych przeprowadzono ze zmiennym progiem odcięcia, oddzielnie dla każdego miesiąca. Taki sposób delimitacji susz i niżówek jest proponowany przez Van Loon et al. (2014) i stosowany również w polskiej literaturze hydrologicznej (Bochenek, 2017; Tomaszewski, 2018). Porównawcze badania odpływu ze zlewni Bystrzanki z zastosowaniem stałego i zmiennego poziomu odcięcia wskazały na krótszy czas trwania niżówek przy zmiennym progu odcięcia (Bochenek, 2017). Zmienny próg odcięcia jest zatem bardziej restrykcyjny niż stały próg, przyjęty dla przypływów w całym roku.

W celu wskazania kierunków zmian czasu trwania przepływów niżówkowych i ich przebiegu w ciągu roku, obliczono pięcioletnie średnie ruchome liczby dni dla każdego miesiąca, po uprzedniej standaryzacji danych. Standaryzację danych przeprowadzono ze względu na zróżnicowaną średnią liczbę dni z niżówką w badanych zlewniach oraz jej zmienność w poszczególnych latach (odchylenie standardowe).

W badaniach wykorzystano współczynnik zmienności odpływu $\left(C_{v}\right)$, który obliczono zgodnie z formułą (równanie 1):

$$
C_{v}=\frac{\sigma}{\bar{x}} \cdot 100
$$

gdzie: $\sigma$-odchylenie standardowe, $\bar{x}$ - wartość średnia. 
Ponadto obliczono współczynnik odpływu $\left(R_{c}\right)$, który według Wang et al. (2014) jest jedną z prostszych metod pozwalających na określenie m.in. wpływu zmian pokrycia terenu i użytkowania ziemi na generowanie odpływu. Współczynnik ten opisuje relację wysokości odpływu do wysokości opadu w tym samym czasie (równanie 2):

$$
R_{c}=\frac{H}{P} \cdot 100
$$

gdzie: $H$ - odpływ roczny (mm), $P$ - roczna suma opadu atmosferycznego $(\mathrm{mm})$.

Warstwę niedoboru odpływu, spowodowanego przepływem niżówkowym w ciągu doby $(d)$, obliczono jako różnicę między dobowym odpływem odpowiadającym progowej wartości niżówki (Vp) (całkowitej lub głębokiej) a rzeczywistym odpływem dobowym (V), podzielonym przez powierzchnię zlewni $(A)$, według wzoru (równanie 3):

$$
d=\frac{V p-V}{A}
$$

Do oceny warunków termiczno-opadowych posłużono się wskaźnikiem suchości klimatu $A$ (Ped, 1977), opisanym formułą (równanie 4):

$$
A=\sum_{i=1}^{n}\left[\frac{T-\bar{T}}{\sigma_{T}}-\frac{\operatorname{Pr}-\overline{\mathrm{Pr}}}{\sigma_{P}}\right]
$$

gdzie: $\sigma$-odchylenie standardowe od średnich wieloletnich temperatury powietrza $(\bar{T})$ i sum opadów $(\bar{P} r)$. Wskaźnik ten przyjmuje wartości dodatnie dla okresów suchych, co jest wynikiem dodatnich odchyleń temperatury powietrza i ujemnych odchyleń sum miesięcznych opadów, natomiast wartości ujemne dla okresów wilgotnych, co z kolei jest wynikiem ujemnego odchylenia średniej miesięcznej temperatury powietrza i dodatniego odchylenia sum opadów. Według Kolevej i Alexandrova (2008) wartości wskaźnika A: 1-2 wskazują na występowanie oznak suszy, 2-3 oznaczają umiarkowaną suszę, >3 silną suszę. Wskaźnik suchości klimatu $A$ jest współcześnie stosowany w opracowaniach klimatologicznych (Podstawczyńska, 2010; Jania i Zwoliński, 2011; Skowera et al., 2016; Bochenek et al., 2018; Kopcińska et al., 2018).

Parowanie terenowe obliczono dla okresów rocznych według formuły Turc (1964) (równanie 5):

$$
E=\frac{P}{\sqrt{0,9+\frac{P^{2}}{L^{2}}}}
$$

gdzie: $E$ - parowanie terenowe $(\mathrm{mm}), P$ - roczna suma opadu $(\mathrm{mm}), L-\mathrm{tzw}$. potencjał ewaporometryczny, obliczany według wzoru (równanie 6):

$$
L=300+25 t+0,05 t^{3}
$$

Dynamikę pokrycia terenu przedstawiono za pomocą wskaźnika tempa zmian pokrycia terenu $d_{n}(F A O, 1996)$ między przekrojami czasowymi, dla których wykonano mapy pokrycia terenu i użytkowania ziemi według formuły (równanie 7):

$$
d_{n}=\left(\left(\frac{S 1}{S 2}\right)^{\frac{1}{n}}-1\right) \cdot 100
$$


gdzie: $d_{n}$ - tempo zmian (\%), $S 1$ - powierzchnia typu pokrycia terenu i użytkowania ziemi pierwszym okresie, $S 2$ - powierzchnia typu pokrycia terenu i użytkowania ziemi w drugim okresie, $n$ - liczba lat między okresem pierwszym a drugim. Powyższa formuła zakłada ciągłość zmiany pokrycia terenu, obliczanej na podstawie danych dyskretnych, będących stanem pokrycia terenu w danym roku.

Na podstawie map pokrycia terenu w badanych zlewniach obliczony został wskaźnik synantropizacji S (Roo-Zielińska et al., 2007). Poszczególnym kategoriom pokrycia terenu i użytkowania ziemi przypisano wartości liczbowe zaproponowane przez Roo-Zielińską et al. (2007), tj. lasy - 1 punkt synantropizacji; użytki zielone - 2; grunty orne - 4; powierzchnie zabudowane - 5, które pomnożono przez ich powierzchnie. Suma iloczynów podzielona przez całkowitą powierzchnię zlewni stanowiła wskaźnik synantropizacji $S$.

Przeprowadzone zostały badania trendów temperatury powietrza, opadu, odpływu, czasu trwania niżówek i niedoboru odpływu podczas niżówek w wieloleciu 1988-2017. Do realizacji tego celu wykorzystano równanie trendu liniowego (równanie 8):

$$
y=\alpha x+b
$$

gdzie: $y$ - zmienna zależna (objaśniana), $x$ - zmienna niezależna (objaśniająca, w tym przypadku $T$ - okres 1 roku), $\alpha$ - współczynnik trendu liniowego, $b$ - wyraz wolny.

\section{Wyniki}

\section{Zmiany pokrycia terenu i użytkowania ziemi}

Na obszarze Karpat Zachodnich w okresie ostatnich 30 lat nastąpiły zmiany pokrycia terenu związane m.in. ze zmianami politycznymi i gospodarczymi po 1989 r. Pod względem pokrycia terenu największe różnice notowano w zlewniach pogórskich (ryc. 2). W zlewni Skawinki odnotowano wzrost obszarów zabudowanych o 495\% między rokiem 1990 a 2018, na który miało wpływ położenie zlewni na południowy-zachód od Krakowa i wzrost semiurbanizacji, przejawiającej się zwiększeniem powierzchni zabudowy jednorodzinnej kosztem zmniejszenia łącznej powierzchni małych działek rolnych. Udział powierzchni leśnej wzrósł z 23\% (w 1990 r.) do 36\% (w 2018 r.). W zlewni Stobnicy, podobnie jak w zlewni Skawinki, odnotowano wzrost obszarów zabudowanych (o 99\%) oraz powierzchni leśnej (o 23\%).

W zlewniach beskidzkich notowano znacznie niższy udział gruntów ornych w porównaniu do zlewni pogórskich z powodu mniejszej żyzności gleb, utworzonych na zwietrzelinie piaskowcowej, większych spadków terenu i niższej temperatury powietrza (krótszy okres wegetacyjny). W zlewniach beskidzkich spadek powierzchni gruntów ornych wyniósł 36\% (Osława) i 46\% (Soła). Równocześnie w obszarach tych nastąpił wzrost użytków zielonych oraz niewielki wzrost powierzchni leśnej (ryc. 2). Obszar beskidzki, podobnie jak pogórski, charakteryzował sie wzrostem obszarów zabudowanych, maksymalnie o 54\% (Osława).

Średnie roczne tempo zmian zachodzących w pokryciu terenu $\left(d_{n}\right)$ było najwyższe w pogórskiej zlewni Skawinki, wyniosło 5,8\% i było skutkiem prawie pięciokrotnego wzrostu powierzchni obszarów zabudowanych. Największe tempo zmiany wystąpiło w tej zlewni między 2006 i 2018 r. (11,7\%), spowodowane wzrostem powierzchni zabudowanych (o 490\%) i zmniejszeniem powierzchni gruntów ornych (o 32\%). W pozostałych zlewniach średnie $d_{n}$ wynosiło od 0,4 (Soła) do 1,5\% (Stobnica). 

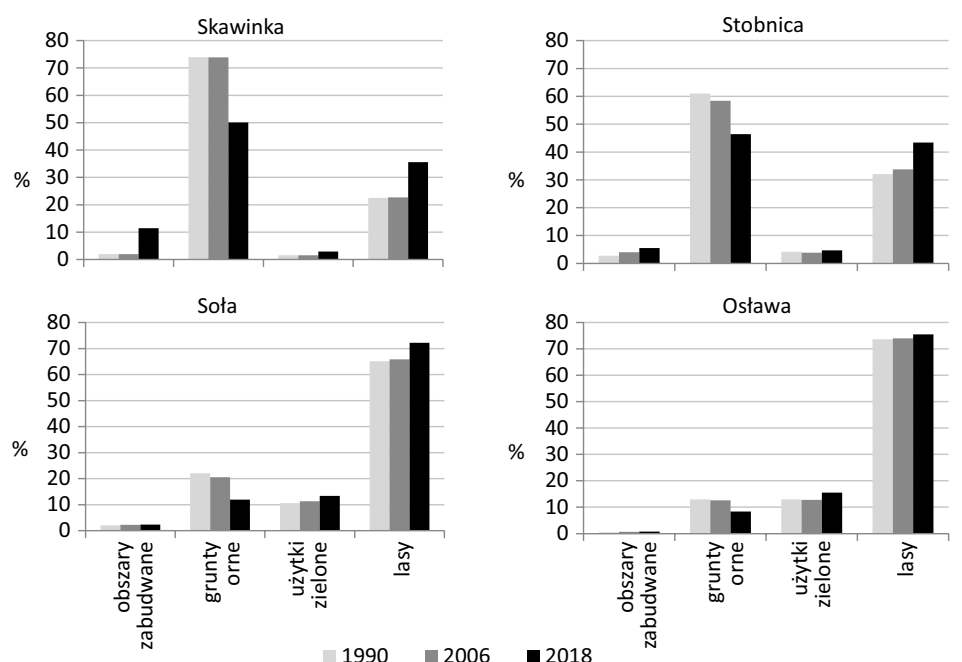

Ryc. 2. Procentowy udział pokrycia terenu i użytkowania ziemi w analizowanych zlewniach w 1990, 2006 oraz 2018 r.

Percentage shares of land use and land cover in the analysed catchment in 1990, 2006 and 2018

Najniższy średni wskaźnik synantropizacji $S$, wskazujący na zachowanie naturalnych walorów środowiska, wystąpił w zlewni Osławy $(1,5)$, o największym udziale lasów i małej gęstości zaludnienia (13os./ $/ \mathrm{km}^{2}$ ), natomiast najwyższą wartość przyjął w zlewni Skawinki $(3,2)$, w których działalność człowieka w okresie badanych 30 lat była ekspansywna, spowodowana korzystnymi warunkami środowiska i bliskością dużego ośrodka miejskiego - Krakowa.

\section{Opad i odpływ rzeczny}

Średnie roczne sumy opadu, obliczone dla referencyjnych posterunków opadowych, kształtowały się w zlewniach pogórskich od $751 \mathrm{~mm}$ (Skawinka) do 796 mm (Stobnica), a w zlewniach beskidzkich od 987 mm (Osława) do 1026 mm (Soła) (tab. 2). Zmiany warunków termicznych przejawiały się wzrostem temperatury powietrza, głównie w ciepłym półroczu hydrologicznym (maj-październik), opisane statystycznie istotnymi $(p<0,05)$ współczynnikami trendu liniowego. Sumy opadu w półroczu zimowym nie wykazywały trendu. W półroczu letnim współczynnik trendu a opadu we wszystkich zlewniach przyjął kierunek dodatni, lecz współczynnik korelacji trendu nie przekroczył progu $\alpha=0,05$. W badanym okresie największą częstość rocznych wartości wskaźnika suchości klimatu A>2 (umiarkowana i silna susza) stwierdzono w zlewni Skawinki (13 lat); w pozostałych zlewniach liczba lat spełniających powyższe kryterium wyniosła od 8 do 11 . W okresie badanych 30 lat wskaźnik $A$ przyjął statystycznie istotne trendy roczne tylko dla półrocza letniego. Zatem wzrost opadu nie rekompensuje strat związanych z parowaniem terenowym, determinowanym przez wzrost temperatury.

Spośród badanych zlewni najwyższą średnią roczną sumą odpływu charakteryzowała się zlewnia Soły (661,5 mm), natomiast najniższą - zlewnia Stobnicy (296,7 mm) (tab. 2). Średni odpływ z wybranych zlewni pogórskich był bardzo podobny. Najwyższe roczne 
sumy odpływu ze wszystkich zlewni wystąpiły w 2010 r. i spowodowane były wysokimi miesięcznymi sumami opadów w maju, które na referencyjnych posterunkach opadowych przekroczyły $300 \mathrm{~mm}$ (ryc. 3). Obliczony współczynnik zmienności $\left(C_{v}\right)$ rocznego odpływu w omawianym trzydziestoleciu był o połowę niższy w zlewniach beskidzkich (22-24\%) w porównaniu do zlewni pogórskich (40-45\%) (tab. 2). Przeciętny współczynnik odpływu w zlewniach pogórskich wyniósł 37\% (Stobnica) i 40\% (Skawinka), natomiast w zlewniach beskidzkich był wyższy - 60\% (Osława) i 64\% (Soła), spowodowany większymi nachyleniami terenu i spadkami koryt rzecznych oraz wyższymi sumami opadów, zwiększającymi możliwość wystąpienia spływu powierzchniowego. Ewapotranspiracja, jako „rozchodowy” element bilansu wodnego, nie odegrała znaczącej roli w kształtowa-
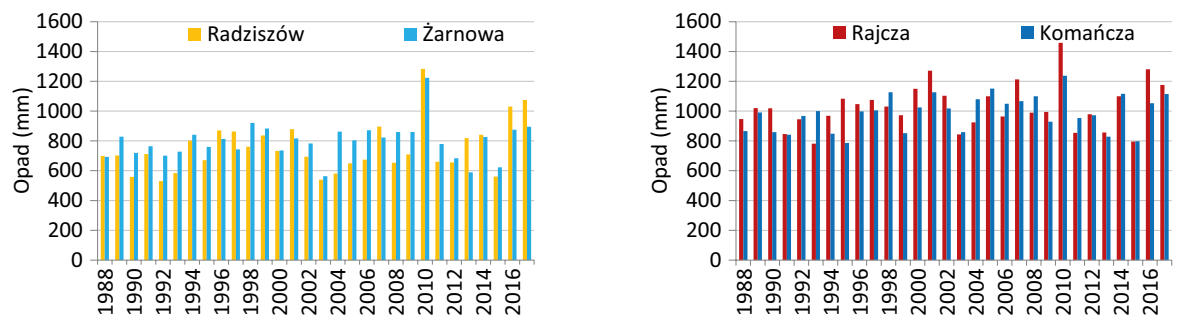

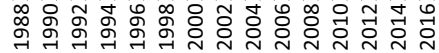
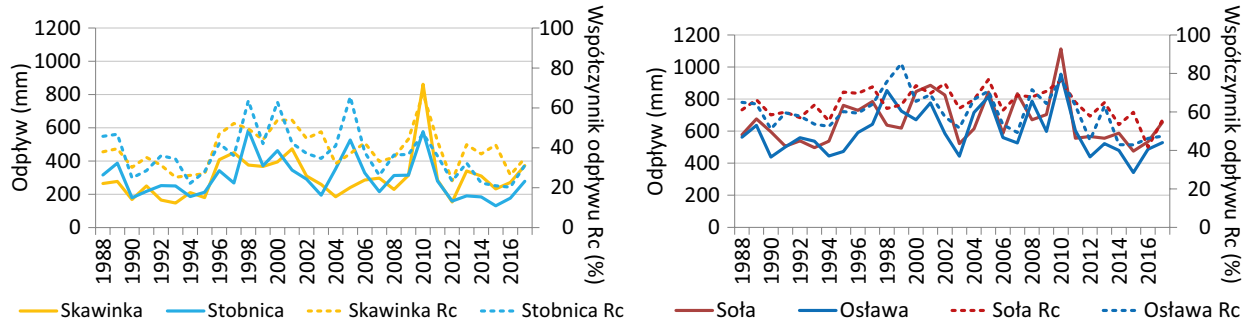

Ryc. 3. Roczne sumy opadu, odpływ i współczynnik odpływu w badanych zlewniach w latach 1988-2017

Annual precipitation totals, runoff depth and runoff coefficient in the studied catchments in the years 1988-2017

Tabela 2. Wybrane charakterystyki opadu i odpływu w analizowanych zlewniach karpackich w latach 1988-2017 Selected characteristics of precipitation and runoff in the studied Carpathian catchments in 1988-2017

\begin{tabular}{|c|c|c|c|c|c|c|c|}
\hline \multirow{3}{*}{ Zlewnia } & \multirow{2}{*}{$\begin{array}{c}\text { Średnia roczna } \\
\text { suma opadu } \\
\text { (min.-maks.) }\end{array}$} & \multirow{2}{*}{$\begin{array}{c}\text { Średni roczny } \\
\text { odpływ } \\
\text { (min.-maks.) }\end{array}$} & \multirow{2}{*}{ 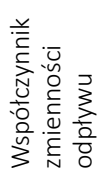 } & \multirow{2}{*}{ 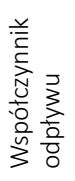 } & \multicolumn{3}{|c|}{$\begin{array}{l}\text { Zależność rocznych sum odpływu } \\
\text { od sum opadu }\end{array}$} \\
\hline & & & & & $\begin{array}{l}\text { Współczyn- } \\
\text { nik determi- } \\
\text { nacji } R^{2}\end{array}$ & $\begin{array}{c}\text { Współczyn- } \\
\text { nik regresji } \\
\text { liniowej } a\end{array}$ & $\begin{array}{c}\text { Poziom } \\
\text { istotności } \\
\text { statystycznej }\end{array}$ \\
\hline & $\mathrm{mm}$ & $\mathrm{mm}$ & $\%$ & $\%$ & - & - & - \\
\hline Skawinki & $\begin{array}{c}750,7 \\
(530,7-1283,3)\end{array}$ & $\begin{array}{c}303,1 \\
(147,4-862,0\end{array}$ & 45,1 & 39,5 & 0,628 & 0,793 & $<0,001$ \\
\hline Stobnicy & $\begin{array}{c}795,6 \\
(563,0-1223,7)\end{array}$ & $\begin{array}{c}296,7 \\
(130,7-586,0)\end{array}$ & 40,2 & 36,8 & 0,378 & 0,615 & $<0,001$ \\
\hline Soły & $\begin{array}{c}1026,1 \\
782,1-1458,0)\end{array}$ & $\begin{array}{c}661,5 \\
(475,9-1113,9)\end{array}$ & 22,1 & 64,2 & 0,631 & 0,794 & $<0,001$ \\
\hline Osławy & $\begin{array}{c}987,0 \\
(786,0-1237,4)\end{array}$ & $\begin{array}{c}593,6 \\
(342,3-955,8)\end{array}$ & 23,9 & 59,9 & 0,456 & 0,675 & $<0,001$ \\
\hline
\end{tabular}


niu różnicy średniego współczynnika odpływu między badanymi zlewniami. Na wybranych obszarach badawczych średnie roczne sumy parowania terenowego, obliczonego metodą Turca (1964), były zbliżone i kształtowały się od 444,4 mm w zlewni Stobnicy do 461,0 mm w zlewni Soły.

Zależność rocznych sum odpływu (zmienna zależna) w profilach hydrometrycznych od sum opadów (zmienna niezależna) na referencyjnych stacjach opadowych we wszystkich badanych zlewniach była istotna statystycznie, a współczynnik determinacji $R^{2}$ Pearsona przyjął wartości od 0,378 w zlewni Stobnicy do 0,631 w zlewni Soły. Współczynnik regresji liniowej $a$ przyjął wartości w zakresie od 0,675 w zlewni Osławy do 0,794 w zlewni Soły. Zarówno współczynnik regresji $\alpha$, jak i współczynnik determinacji $R^{2}$ zmniejszały się w kierunku wschodnim, świadcząc o słabszym uzależnianiu obydwu badanych zmiennych. Przyczyną takiej sytuacji był wzrost kontynentalnych cech klimatu w kierunku wschodnim, przejawiający się wzrostem temperatury powietrza oraz niższymi sumami opadów w okresie letnim, w porównaniu z Beskidami Zachodnimi. Ważną rolę w kształtowaniu relacji opad-odpływ odegrały: wysoki udział powierzchni leśnej i niski udział zabudowy we wschodniej części badanego obszaru, sprzyjające wzrostowi retencji i parowania terenowego.

\section{Przepływy niżówkowe}

Mediana liczby dni z przepływem niżówkowym (niżówka całkowita) kształtowała się od 107 w zlewni Skawinki do 118 w zlewni Osławy (tab. 3). O dynamice czasu trwania przepływów niżówkowych w kolejnych latach świadczy współczynnik zmienności $C_{v^{\prime}}$ który w zlewniach pogórskich wyniósł 57\% (zlewnia Skawinki) i 62\% (zlewnia Stobnicy), a w zlewniach beskidzkich był niższy i przyjął wartości 30\% (zlewnia Soły) i 41\% (zlewnia Osławy). W zlewniach pogórskich średni roczny deficyt odpływu niżówkowego wyniósł 9,2 mm, natomiast w zlewniach beskidzkich był ponad dwukrotnie wyższy - 21,5 mm. Spośród badanych zlewni najwyższą medianę czasu trwania przepływów niżówkowych i deficytu odpływu stwierdzono dla zlewni Osławy i Stobnicy, wysuniętych w kierunku wschodnim. Największe niedobory odpływu niżówkowego stwierdzono w beskidzkich dorzeczach Soły i Osławy, charakteryzujących się dużym udziałem powierzchni leśnych (ryc. 2).

Udział niżówek głębokich w całkowitym czasie trwania przepływu niżówkowego stanowił około $12 \%$ w zlewniach pogórskich i 14\% w zlewniach beskidzkich. Średni roczny deficyt odpływu podczas niżówek głębokich w zlewniach pogórskich wyniósł 0,55 mm, a w beskidzkich 1,53 mm, stanowiąc średnio 1,4\% i 2,3\% deficytu odpływu niżówkowego ogółem.

Liczbę dni w roku z przepływem niżówkowym z podziałem na przepływ niżówki płytkiej (sd) i niżówki głębokiej (dd) przedstawiono na rycinie 4. Największa liczba dni z przepływami niżówkowymi w poszczególnych zlewniach występowała w różnych latach: w zlewni Skawinki w 1993 r., Stobnicy - w 2015 r., Soły - w 2012 r. i Osławy - w 2015 r. Podobne zróżnicowanie wystąpiło dla najmniejszej liczby dni z przepływami niżówkowymi: dla Skawinki i Stobnicy - w 1998 r., Soły - w 1995 r. i Osławy - w 2010 r.

Analiza liczby dni z przepływem niżówkowym w poszczególnych miesiącach wykazała, że w zlewniach beskidzkich w latach 1998-2007 wyraźnie zaznaczył się okres z mniejszą liczbą dni z niżówką, poprzedzony mniejszą częstością dni z przepływem niżówkowym w miesiącach wiosennych (ryc. 6A). W zlewniach pogórskich okres mniejszej liczby dni z niżówką szczególnie widoczny był w latach 1993-2002 (ryc. 5A). W zlewniach pogórskich 
Tabela 3. Przepływy niżówkowe w analizowanych zlewniach karpackich w latach 1988-2017

Low flows in the Carpathian catchments analysed in the years 1988-2017

\begin{tabular}{|c|c|c|c|c|c|}
\hline \multirow{2}{*}{ Rzeka } & \multirow{2}{*}{$\begin{array}{l}\text { Wielkości } \\
\text { statystyczne }\end{array}$} & \multicolumn{2}{|c|}{$\begin{array}{c}\text { Średnia roczna liczba dni z przepływem } \\
\text { niżówkowym }\end{array}$} & \multicolumn{2}{|c|}{ Średni roczny deficit odpływu (mm) } \\
\hline & & Niżówka całkowita & Niżówka głęboka & Niżówka całkowita & Niżówka głęboka \\
\hline \multirow{4}{*}{ Skawinka } & Mediana & 107 & 8 & 7,3 & 0,12 \\
\hline & Średnia & 112 & 19 & 8,8 & 0,54 \\
\hline & Minimalna & 12 & 0 & 0,2 & 0,00 \\
\hline & Maksymalna & 246 & 90 & 24,7 & 2,81 \\
\hline \multirow{4}{*}{ Stobnica } & Mediana & 116 & 8 & 8,9 & 0,05 \\
\hline & Średnia & 111 & 18 & 9,5 & 0,55 \\
\hline & Minimalna & 2 & 0 & 0,0 & 0,00 \\
\hline & Maksymalna & 260 & 103 & 28,5 & 3,48 \\
\hline \multirow{4}{*}{ Soła } & Mediana & 108 & 13 & 18,7 & 0,43 \\
\hline & Średnia & 111 & 18 & 19,3 & 0,84 \\
\hline & Minimalna & 53 & 0 & 4,2 & 0,00 \\
\hline & Maksymalna & 185 & 62 & 34,7 & 4,15 \\
\hline \multirow{4}{*}{ Osława } & Mediana & 118 & 12 & 21,6 & 0,79 \\
\hline & Średnia & 109 & 18 & 23,6 & 2,22 \\
\hline & Minimalna & 31 & 0 & 3,4 & 0,00 \\
\hline & Maksymalna & 208 & 83 & 79,0 & 20,51 \\
\hline
\end{tabular}
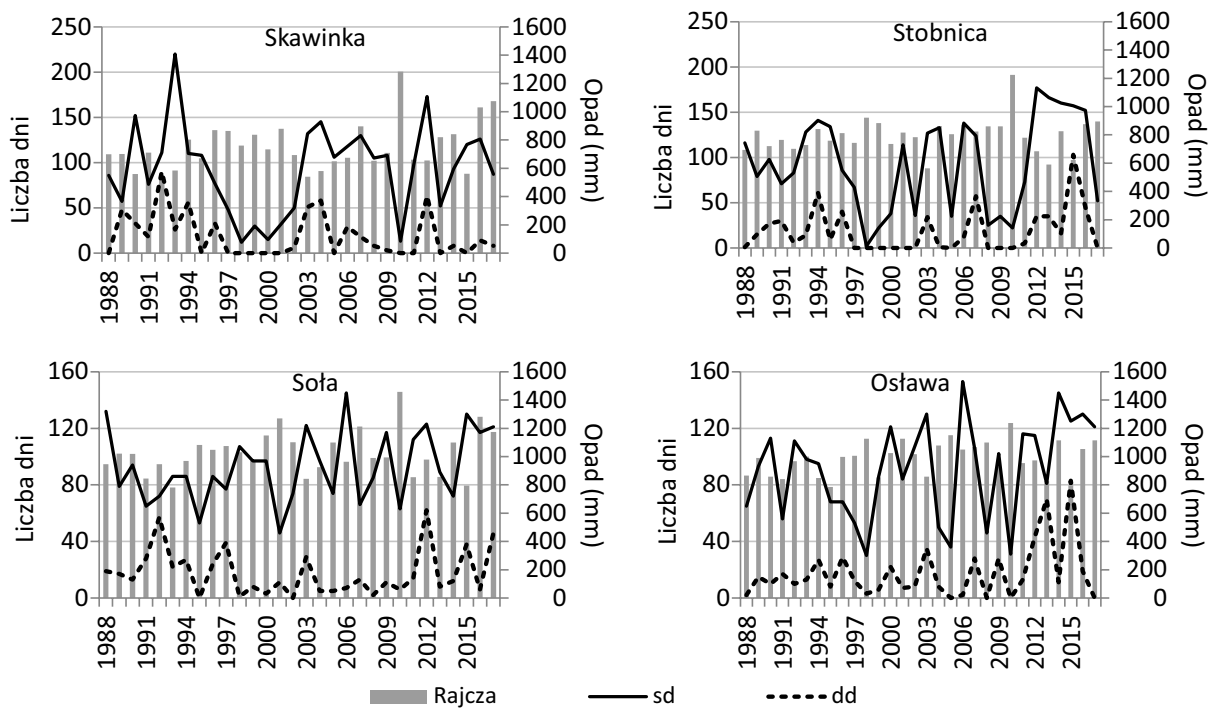

Ryc. 4. Liczba dni z przepływem niżówki płytkiej (sd) i niżówki głębokiej (dd) w badanych zlewniach pogórskich i beskidzkich w latach 1988-2017

Number of days with minor drought (sd) and severe drought (dd) in the foothill and Beskid Mountain catchments studied, in the period 1988-2017 

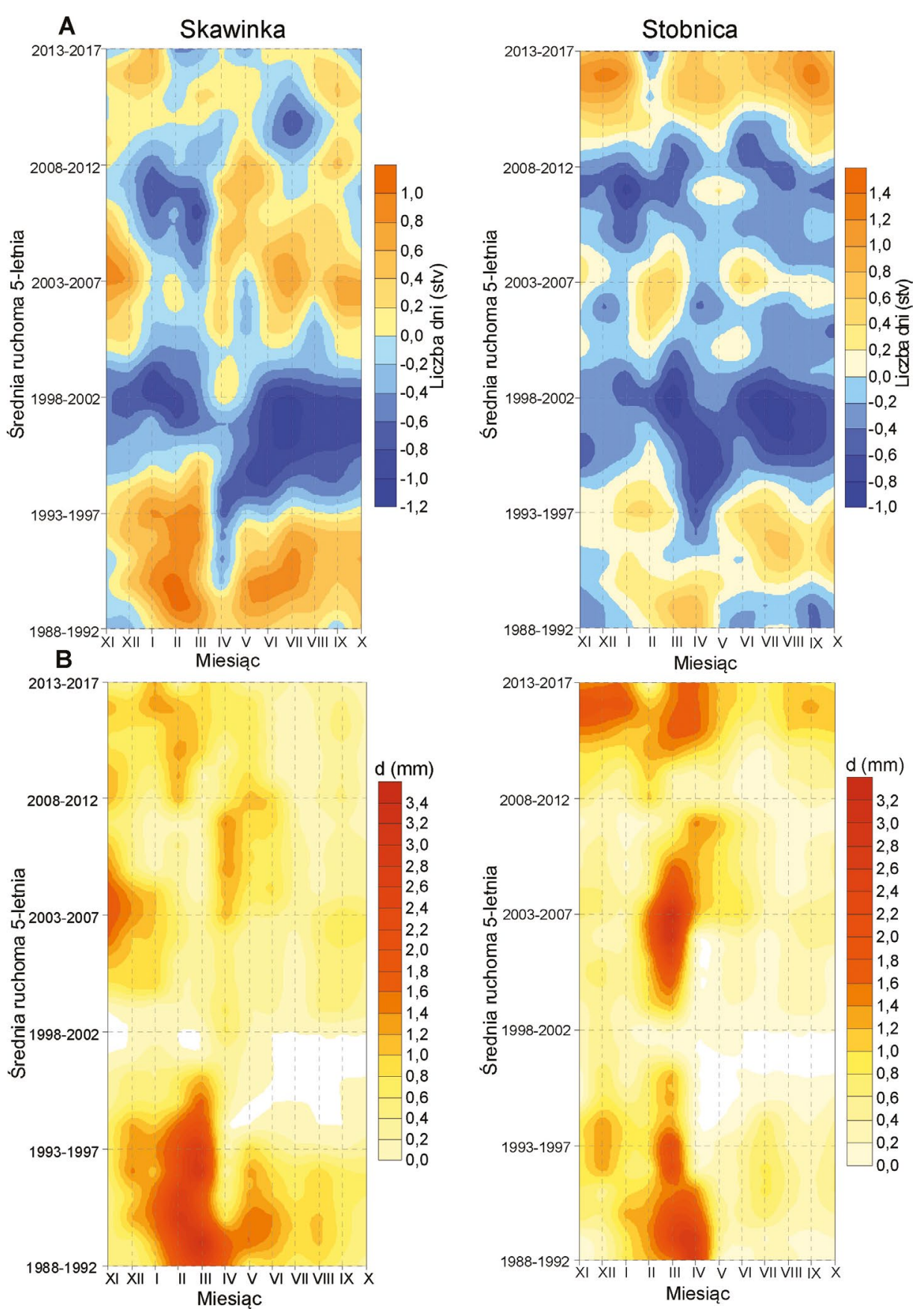

Ryc. 5. Rozkład liczby dni z przepływem niżówkowym (A) i niedoboru odpływu nižówkowego (B) w poszczególnych miesiącach w zlewniach pogórskich w wieloleciu 1988-2017 (średnie ruchome 5-letnie; dane standaryzowane)

Distribution of numbers of days with low flow (A) and drought streamflow deficit volume (B) in the foothill catchments in the years 1988-2017 (5-year moving average; standardised data) 
A

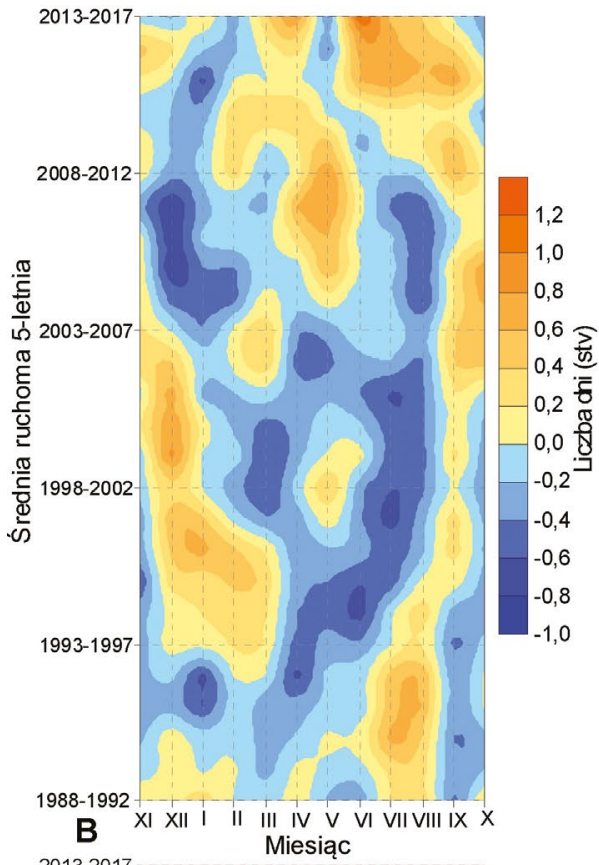

Soła

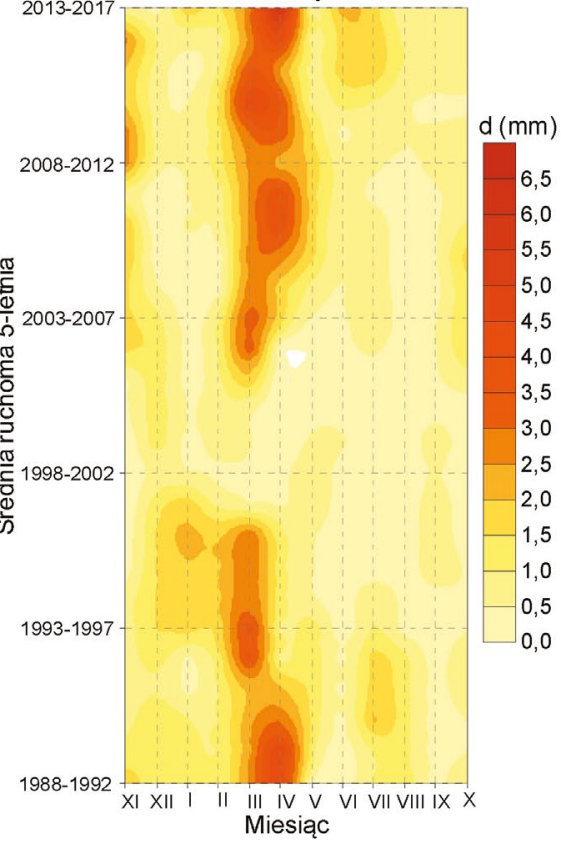

Osława

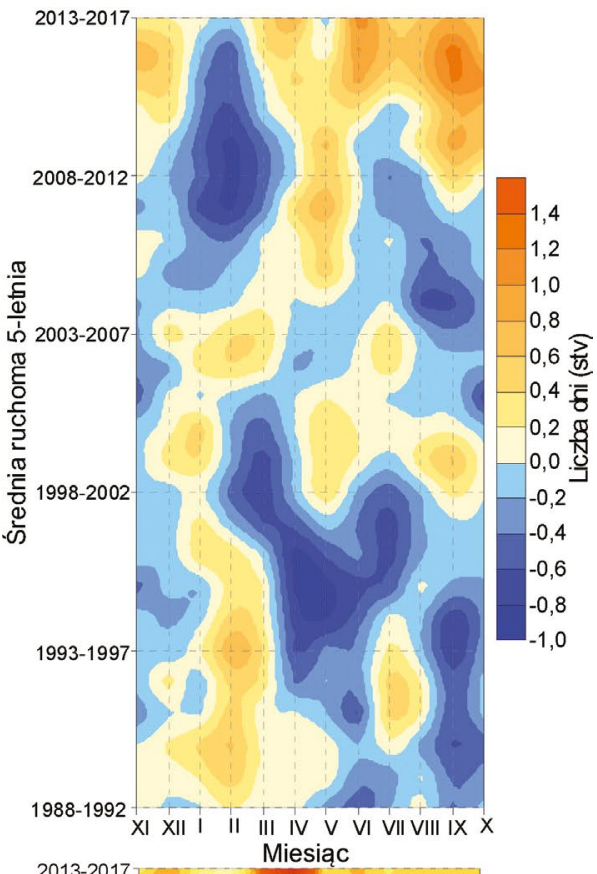

Ryc. 6. Rozkład liczby dni z przepływem niżówkowym (A) i niedoboru odpływu niżówkowego (B) w poszczególnych miesiącach w zlewniach beskidzkich w wieloleciu 1988-2017 (średnie ruchome 5-letnie; dane standaryzowane)

Distribution of numbers of days with low flow (A) and drought streamflow deficit volume (B) in the Beskid Mountain catchments in the years 1988-2017 (5-year moving average; standardised data) 
odnotowano także wzrost przepływów niżówkowych w poszczególnych miesiącach w roku dla okresu 1988-1997, szczególnie widoczny w zlewni Skawinki. W zlewniach beskidzkich okresy z większą liczbą dni z przepływem niżówkowym są krótsze, występujące naprzemiennie z okresami wzrostu przepływu.

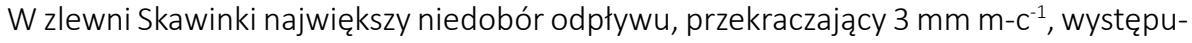
jący głównie w zimowym półroczu hydrologicznym, zaobserwowano w latach 1988-1997 (ryc. 5B). Największy niedobór odpływu w tej zlewni wystąpił w marcu 1989 r. - 7,6 mm. W zlewni Stobnicy wystąpiło kilka okresów znaczącego niedoboru odpływu, przekracza-

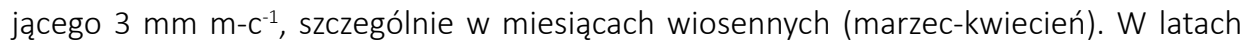
2013-2017 znaczący niedobór odpływu dotyczył całego roku. Maksymalna miesięczna wysokość niedoboru odpływu wyniosła 6,9 mm w kwietniu $1991 \mathrm{r}$. W tej samej części roku w zlewni Soły, prawie w całym okresie badań występował niedobór odpływu przekra-

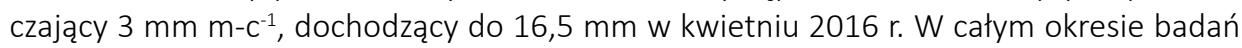
w zlewni Osławy w półroczu zimowym stwierdzono niedobór odpływu spowodowanego

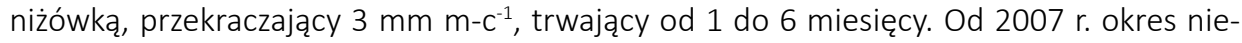
doboru odpływu wzrastał (ryc. 6B). W marcu 2012 r. deficyt odpływu niżówkowego w tej zlewni osiągnął $36 \mathrm{~mm}$.

\section{Dyskusja}

W analizowanych zlewniach karpackich odnotowano znaczące zmiany pokrycia terenu i użytkowania ziemi w latach 1990-2018, przejawiające się głównie wzrostem powierzchni utwardzonych (maksymalnie o 495\% - pogórska zlewnia Skawinki), powierzchni leśnej (maksymalnie o 58\% - zlewnia Skawinki), użytków zielonych (maksymalnie o 87\% - zlewnia Skawinki) i spadkiem powierzchni gruntów ornych (maksymalnie o 46\% - zlewnia Soły). Wzrost powierzchni utwardzonych obserwowano również w innych zlewniach karpackich (Kijowska-Strugała, 2015; Kroczak et al., 2016; Bucała-Hrabia, 2018). Znaczny wzrost powierzchni utwardzonych (nieprzepuszczalnych) wpływa na obieg wody, tzn. zmniejsza objętość wody wsiąkającej w glebę, a zwiększa wysokość spływu powierzchniowego i skraca czas koncentracji wezbrania w korycie rzeki (Soja, 2002). W efekcie obserwuje się zmniejszenie zasobów wodnych gleby i wzrost prawdopodobieństwa i intensywności hydrologicznych zjawisk ekstremalnych (Löschner et al., 2016). Zmiany pokrycia terenu i użytkowania ziemi obserowane są również w innych krajach Europy Środkowej i Wschodniej i związane są głównie z transformacją gospodarczą po 1989 r., która obniżyła opłacalność produkcji rolnej (Baessler i Klotz, 2006; Munteanu et al., 2014).

Analiza rocznych sum opadów atmosferycznych w wybranych zlewniach pogórskich i beskidzkich nie wykazała żadnych istotnych statystycznie trendów. Podobne prawidłowości obserwowano w innych obszarach Karpat (Niedźwiedź et al., 2009; Wypych et al., 2018). Stwierdzono natomiast występowanie statystycznie istotnego trendu rosnącego średniej temperatury powietrza w ciepłym półroczu hydrologicznym. Uzyskane wyniki są zgodne z rezultatami Żmudzkiej (2010), które wykazały w okresie letnim (VI-VIII) wyższy i statystycznie istotny rosnący trend temperatury powietrza w Tatrach w porównaniu z obszarami nizinnymi Polski. We wszystkich zlewniach odnotowano dodatnią istotną statystycznie $(p<0,05)$ zależność opadów i odpływu. Wykazano, że zarówno współczynnik regresji $\alpha$, jak i współczynnik determinacji $R^{2}$ osiągał wyższe wartości w zlewniach poło- 
żonych w zachodniej części Karpat (Skawinka, Soła) w porównaniu do zlewni położonych we wschodniej części (Stobnica, Osława). Ważną rolę w kształtowaniu relacji opad-odpływ odegrał wysoki udział powierzchni leśnej i niski udział zabudowy we wschodniej części badanego obszaru. Miler (2012) wykazał, że wraz ze zmniejszeniem się lesistości zwiększa się odpływ efektywny, a tym samym spadają możliwości retencyjne zlewni. Kostuch (2004) wykazał, że w półroczach letnich w zlewni o mniejszej lesistości zasoby wody wyczerpują się szybciej niż w zlewni z większą powierzchnią lasu.

W zlewniach beskidzkich średnia wartość współczynnika odpływu była o 32\% wyższa niż w zlewniach pogórskich. Znaczącą rolę w kształtowaniu współczynnika odpływu w wybranych zlewniach odegrał rozkład opadów w ciągu roku. Wyższy udział opadów deszczu w letnim półroczu hydrologicznym występował w zlewni Skawinki i Soły, zgodnie ze spostrzeżeniami Kaczorowskiej (1962). Ponadto stwierdzono statystycznie istotny $(p<0,05)$ wpływ udziału powierzchni lasów i gruntów ornych na współczynnik odpływu (ryc. 7). Wykazano zależności: dodatnią między udziałem powierzchni leśnej oraz ujemną - między udziałem powierzchni gruntów ornych a współczynnikiem odpływu. Badania Merza i Bloschla (2009) wykazały, że współczynnik odpływu może odzwierciedlać złożony wpływ pokrycia terenu i użytkowania ziemi na retencjonowanie wody w zlewni. Współczynnik odpływu był uzależniony w analizowanych zlewniach od wskaźnika synantropizacji $S$, odzwierciedlającego nasilenie antropopresji. W zlewniach beskidzkich (Soła i Osława) przy niższych średnich wartościach wskaźnika synantropizacji wystąpiły wyższe wartości współczynnika odpływu w porównaniu do zlewni pogórskich, charakteryzujących się wyższym średnim wskaźnikiem synantropizacji i niższym współczynnikiem odpływu. Wskazuje to, że pokrycie terenu i jego zmiany nie są jedynym czynnikiem determinującym współczynnik odpływu w analizowanych zlewniach. Ważną rolę odgrywa wysokość opadu i jego dystrybucja między składnikami odpływu, nachylenie terenu i gęstość sieci rzecznej.

Średni czas trwania przepływów niżówkowych w zlewniach pogórskich wyniósł 112 dni, o 2 dni dłużej niż w zlewniach beskidzkich. Ponadto w zlewniach beskidzkich współczynnik zmienności czasu trwania niżówek był niższy (30\% i 41\%) niż w zlewniach pogórskich (58\% i 62\%). We wszystkich badanych zlewniach trendy czasu trwania przepływów niżówkowych były nieistotne statystycznie. Główna przyczyną jest duża czasowa zmienność natężenia przepływu w Karpatach Zachodnich w kolejnych latach (Punzet, 1996; Soja, 2002;

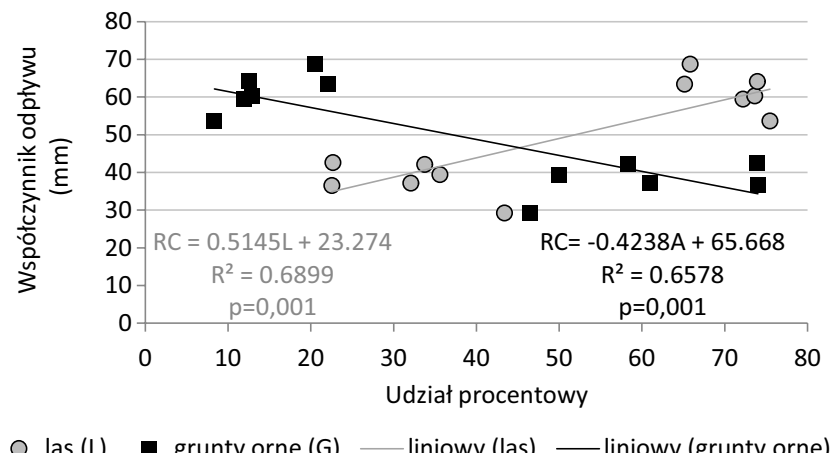

Ryc. 7. Wpływ powierzchni leśnej i gruntów ornych na współczynnik odpływu w analizowanych zlewniach w polskich Karpatach

The impact of forest and arable land on the runoff coefficient in analysed catchments in the Polish Carpathians 
Kijowska-Strugała, 2015; Bochenek, 2017; Kijowska-Strugała et al., 2017; Bochenek, 2019; Kijowska-Strugała i Bucała-Hrabia, 2019). W analizowanych zlewniach pogórskich roczny deficyt odpływu niżówki głębokiej był niższy o 66\% niż w zlewniach beskidzkich, w których obserwowano kilkuletnie okresy wzrostu i spadku niedoboru odpływu. W zlewni Stobnicy, Soły i Osławy odnotowano wzrostowy trend niedoboru odpływu wody, jednak tylko w przypadku Osławy trend był istotny statystycznie na poziomie $p=0,04$. Konsekwencją jest zmniejszanie się zasobów wody w zlewniach. W zlewni Osławy w badanym okresie znacznie zmniejszył się udział gruntów ornych (o 36\%) i zwiększył się udział powierzchni zabudowanych (o 54\%). Dodatkowo, najwyższe spośród analizowanych zlewni średnie nachylenie zlewni i gęstość sieci rzecznej w dorzeczu Soły, sprzyjały wzrostowi prędkości i skróceniu czasu odpływu wody po intensywnych opadach. Kostuch (2004) w dwóch zlewniach górskich wykazał istotny wpływ pokrycia terenu m.in. na liczbę niżówek.

\section{Wnioski}

Wieloletnia analiza (1988-2017) odpływu wody z dwóch zlewni pogórskich (Skawinka i Stobnica) i dwóch beskidzkich (Soła i Osława) w polskich Karpatach umożliwiła rozpoznanie czasu trwania przepływów niżówkowych i niedoboru odpływu. Badane zlewnie charakteryzowały się znaczącymi zmianami pokrycia terenu i użytkowania ziemi w okresie 30 lat, polegającymi głównie na zmniejszeniu powierzchni gruntów ornych oraz wzroście powierzchni użytków zielonych i lasów. Ponadto we wszystkich analizowanych zlewniach odnotowano wzrost obszarów zabudowanych nawet o 495\% (Skawinka). Przeprowadzone badania wykazały, że:

1.przy średniej rocznej sumie opadu kształtującej się od 750-800 mm i odpływie ok. 300 mm, współczynnik odpływu ze zlewni pogórskich wyniósł od 37-40\%. W zlewniach beskidzkich współczynnik odpływu był wyraźnie wyższy i zróżnicowany od 60-64\%, przy opadzie i odpływie wyższym średnio o 33\% i 57\%;

2. mediana liczby dni z przepływem spełniającym kryterium niżówki całkowitej była podobna w zlewniach beskidzkich i pogórskich i wynosiła od 96 do 118 dni. W zlewniach beskidzkich mediana czasu trwania przepływów niżówki głębokiej była blisko dwukrotnie wyższa w porównaniu ze zlewniami pogórskimi;

3. mediana rocznego niedoboru odpływu niżówkowego wykazywała większe zróżnicowanie niż mediana liczby dni z niżówką. W zlewniach pogórskich niedobór odpływu nie przekraczał $10 \mathrm{~mm}$, natomiast w zlewniach beskidzkich wyniósł około $20 \mathrm{~mm}$;

4. w ujęciu regionalnym stwierdzono wydłużanie się czasu trwania przepływów niżówkowych i wzrost niedoboru odpływu w zlewniach położonych we wschodniej części badanego obszaru (zlewnie Stobnicy i Osławy). Znaczącą rolę odegrały uwarunkowania klimatyczne: niższe średnie roczne sumy opadów i mniejszy udział opadów letnich w rocznej ich sumie. Niski udział powierzchni zabudowanych (poniżej 1\% w zlewni Osławy) oraz wysoki udział powierzchni leśnych (ok. 35\% w zlewni Stobnicy) wpłynęły na wzrost retencji oraz parowania terenowego i zmniejszenie objętości wody zasilającej cieki.

Ryciny i tabele, pod którymi nie zamieszczono źródła, są opracowaniami własnymi autorów artykułu. 


\section{Piśmiennictwo}

Baessler, C., \& Klotz, S. (2006). Effects of changes in agricultural land-use on landscape structure and cultivated weed vegetation over the last 50 years. Agriculture, Ecosystems \& Environment, 115(1), 43-50. https://doi.org/10.1016/j.agee.2005.12.007

Bagley, J.E., Desai, A.R., Harding, K.J., Snyder, P.K., \& Foley, J.A. (2014). Drought and Deforestation: Has Land Cover Change Influenced Recent Precipitation Extremes in the Amazon? Journal of Climate, 27, 345-361. https://doi.org/10.1175/JCLI-D-12-00369.1

Bochenek, W. (2017). Nizówki w korycie Bystrzanki w wieloleciu 1991-2015. Monitoring Środowiska Przyrodniczego, 19, 61-68.

Bochenek, W. (2019). Flood in a mountain stream of the Western Carpathians (SE Poland). W: 5-th International Scientific Conference Geobalcanica, 13-14 June, 2019 Sofia, Republic of Bulgaria. Proceedings, Geobalcanica Society (s. 145-152). Skopje. http://dx.doi.org/10.18509/GBP.2019.20

Bochenek, W. (2020). Prawidłowości obiegu wody na obszarze beskidzko-pogórskim Karpat Zachodnich na przykładzie zlewni Bystrzanki w świetle zmian klimatu i działalności człowieka. Prace Geograficzne, 271. Warszawa: IGiPZ PAN.

Bochenek, W., \& Kijowska-Strugała, M. (2018). Long-term droughts changes in a small Carpathian stream channel (Poland). W: 20th EGU General Assembly, EGU2018, Proceedings from the conference held 4-13 April, 2018 in Vienna, Austria, s. 4577.

Bochenek, W., Kijowska-Strugała, M., \& Kiszka, K. (2018). Wieloletnie tendencje warunków klimatycznych w Szymbarku na podstawie wybranych wskaźników. Przegląd Geograficzny, 90(1), 35-52. https://doi.org/10.7163/PrzG.2018.1.2

Bucała-Hrabia, A. (2018). Land use changes and their catchment-scale environmental impact in the Polish Western Carpathians during transition from centrally planned to free-market economics. Geographia Polonica, 91(2), 171-196. https://doi.org/10.7163/GPol.0116

Caruso, B.S. (2002). Temporal and spatial patterns of extreme low flows and effects on stream ecosystems in Otago, New Zealand. Journal of Hydrology, 257(1-4), 115-133. https://doi.org/10.1016/S0022-1694(01)00546-7

Clausen, B., \& Pearson, C.P. (1995). Regional frequency analysis of annual maximum streamflow drought. Journal of Hydrology, 173(1-4), 111-130. https://doi.org/10.1016/0022-1694 (95)02713-Y

Dai, A. (2011). Drought under global warming: a review. Wiley Interdisciplinary Reviews: Climate Change, 2(1), 45-65. https://doi.org/10.1002/wcc.81

Dai, A. (2013). Increasing drought under global warming in observations and models. Nature Climate Change, 3(1), 52-58. https://doi.org/10.1038/nclimate1633

Damborská, I., Gera, M., Melo, M., Lapin, M., \& Nejedlík, P. (2016). Changes in the daily range of the air temperature in the mountainous part of Slovakia within the possible context of global warming. Meteorologische Zeitschrift, 25, 17-35. https://doi.org/10.1127/metz/2015/0569

Douville, H., Ribes, A., Decharme, B., Alkama, R., \& Sheffield, J. (2013). Anthropogenic influence on multidecadal changes in reconstructed global evapotranspiration. Nature Climate Change, 3(1), 59-62. https://doi.org/10.1038/nclimate1632

European Environment Agency. (2019). Dane publiczne EEA. Pobrane z: https://eea.europa.eu/data-and-maps/data/ (20.04.2019).

Fal, B. (2007). Niżówki na górnej i środkowej Wiśle. Gospodarka Wodna, 2, 72-81.

FAO. (1996). Forest resources assessment 1990. Survey of tropical forest cover and study of change processes. 130. Rome: FAO. 
Fleig, A.K., Tallaksen, L.M., Hisdal, H., \& Hannah, D.M. (2011). Regional hydrological drought in north-western Europe: linking a new Regional Drought Area Index with weather types. Hydrological Processes, 25(7), 1163-1179. https://doi.org/10.1002/hyp.7644

Hisdal, H., Tallaksen, L.M., Clausen, B., Peters, E., \& Gustard, A. (2004). Hydrological Drought Characteristics. W: L.M. Tallaksen, \& H.A.J. van Lanen (red.), Hydrological Drought, Processes and Estimation Methods for Streamflow and Groundwater, Developments in Water Science (s. 139-198). Amsterdam: Elsevier.

Hundecha, Y., \& Bardossy, A. (2004). Modeling of the effect of land use changes on the runoff generation of a river basin through parameter regionalization of a watershed model. Journal of Hydrology, 292, 281-295. https://doi.org/10.1016/j.jhydrol.2004.01.002

Huntington, T.J. (2006). Evidence for intensification of the global water cycle: Review and synthesis. Journal of Hydrology, 319, 83-95. https://doi.org/10.1016/j.jhydrol.2005.07.003

IMGW. (2018). Dane publiczne IMGW-PIB. Pobrane z: https://dane.imgw.pl (01.03.2018).

IPCC. (2018). Summary for Policymakers of IPCC Special Report on Global Warming of $1.5^{\circ} \mathrm{C}$ approved by governments.

Jania, J.A., \& Zwoliński, Z. (2011). Ekstremalne zdarzenia meteorologiczne, hydrologiczne i geomorfologiczne w Polsce. Landform Analysis, 15, 51-64.

Kijowska-Strugała, M. (2015). Transport zawiesiny w warunkach zmieniajqcej się antropopresji w zlewni Bystrzanki (Karpaty Fliszowe). Prace Geograficzne, 247, Warszawa: IGiPZ PAN.

Kijowska-Strugała, M. (2019). Sediment variability in a small catchment of the Polish Western Carpathians during transition from centrally planned to free-market economics. Geomorphology, 325, 119-129. https://doi.org/10.1016/j.geomorph.2018.10.008

Kijowska-Strugała, M., \& Bucała-Hrabia, A. (2019). Floods types in a mountain catchment: The Ochotnica River, Poland. Acta geographica Slovenica, 59(1), 23-36. https://doi.org/10.3986/AGS.2250

Kijowska-Strugała, M., Wiejaczka, Ł., Gil, E., Bochenek, W., \& Kiszka, K. (2017). The impact of extreme hydro-meteorological events on the transformation of mountain river channels (Polish Flysch Carpathians). Zeitschrift für Geomorphologie, 61(1), 75-89. https://: doi.org/10.1127/zfg/2017/0434

Koleva, E., \& Alexandrov, V. (2008). Drought in the Bulgarian low regions during the $20^{\text {th }}$ century. Theoretical and Applied Climatology, 92, 113-120. https://doi.org/10.1007/s00704-007-0297-1 Kopcińska, J., Skowera, B., Wojkowski, J., Zając, E., \& Ziernicka-Wojtaszek, A. (2018). Identyfikacja miesięcy suchych i wilgotnych w województwie opolskim na podstawie wybranych wskaźników klimatycznych (1981-2010). Infrastruktura i Ekologia Terenów Wiejskich, 2(1), 421-434.

Kozak, J. (2005). Zmiany powierzchni lasów w Karpatach Polskich na tle innych gór świata, Kraków: Wydawnictwo Uniwersytetu Jagiellońskiego.

Kroczak, R., Bryndal, T., Bucała, A., \& Fidelus, J. (2016). The development, temporal evolution and environmental influence of an unpaved road network on mountain terrain: an example from the Carpathian Mts. (Poland). Environmental Earth Sciences, 75(3), 2561-2578. https://: doi.org/10.1007/s12665-015-5055-6

Kulikowski, R. (2001). Przemiany rolnictwa Polski w latach dziewięćdziesiątych. Daleko czy blisko do Unii Europejskiej?. Studia Obszarów Wiejskich, 1, 71-81.

Lambor, J. (1971). Hydrologia inżynierska. Warszawa: Arkady.

van Loon, A. F., Tijdeman, E., Wanders, N., Van Lanen, H. J., Teuling, A. J., \& Uijlenhoet, R. (2014). How climate seasonality modifies drought duration and deficit. Journal of Geophysical Research: Atmospheres, 119(8), 4640-4656.

van Loon, A.F., \& Laaha, G. (2015). Hydrological drought severity explained by climate and catchment characteristics. Journal of Hydrology, 526, 3-14. https://doi.org/10.1002/2013JD020383 
Lopez-Nicolas, A., Pulido-Velazquez, M., \& Macian-Sorribes, H. (2017). Economic risk assessment of drought impacts on irrigated agriculture. Journal of Hydrology, 550, 580-589. https://doi.org/10.1016/j.jhydrol.2017.05.004

Löschner, L., Herrnegger, M., Apperl, B., Senoner, T., Seher, W., \& Nachtnebel, H.P. (2016). Flood risk, climate change and settlement development: a micro-scale assessment of Austrian municipalities. Regional Environmental Change, 17, 311-322. https://doi.org/10.1007/s10113-016-1009-0

Marszelewski, W., Pius, B., Pawłowski, B., \& Kubiak-Wójcicka, K. (2017). Przebieg rekordowej niżówki Wisły w Toruniu w 2015 roku na tle niżówek z okresu 1951-2015. W: W. Marszelewski (red.), Zasoby i perspektywy gospodarowania wodq w dorzeczu Wisły. Monografie Komisji Hydrologicznej PTG, 4, 151-164.

Merz, R., \& Bloschl, G. (2009). A regional analysis of event runoff coefficients with respect to climate and catchment characteristics in Austria. Water Resources Research, 45, W01405. https://doi.org/10.1029/2008WR007163

Miler, A.T. (2012). Wpływ zmian użytkowania terenu na odpływy wezbraniowe z obszarów o znacznym zalesieniu Roztocza Środkowego. Infrastruktura i Ekologia Terenów Wiejskich, 2(1), 173-182.

Munteanu, C., Kuemmerle, T., Boltiziar, M., Butsic, V., Gimmi, U., Halada, L., \& Lieskovský, J. (2014). Forest and agricultural land change in the Carpathian region - a meta-analysis of long-term patterns and drivers of change. Land Use Policy, 38, 685-697. https://doi.org/10.1016/j.landusepol.2014.01.012

Niedźwiedź, T., Twardosz, R., \& Walanus, A. (2009). Long-term variability of precipitation series in east central Europe in relation to circulation patterns. Theoretical and Applied Climatology, 98(3-4), 337-350. https://doi.org/10.1007/s00704-009-0122-0

Ozga-Zielińska, M., \& Brzeziński, J. (1997). Hydrologia stosowana. Warszawa: PWN.

Ped, D.A. (1977). The analysis of two summer seasons with different weather conditions. Trudy GNIe, 171, 3-19.

Podstawczyńska, A. (2010). Temperatura powietrza i opady atmosferyczne w regionie łódzkim w ostatnim stuleciu. W: J. Twardy, S. Żurek, \& J. Forysiak (red.) Torfowisko Żabieniec: warunki naturalne i zapis zmian paleoekologicznych w jego osadach (s. 63-74). Poznań: Bogucki Wydawnictwo Naukowe.

Punzet, J. (1996). Niskie przepływy i czas ich trwania w górnych biegach rzek zachodniej części Karpat. Gospodarka Wodna, 11, 331-334.

Roo-Zielińska, E., Solon, J., \& Degórski, M. (2007). Evaluation of natural environment based on geobotanical, landscape and soil indicators. Warszawa: IGiPZ PAN.

Seneviratne, S.I., (2012). Climate science: Historical drought trends revisited. Nature, 491, 338-339. https://doi.org/10.1038/491338a

Shabalova, M.V., Van Deursen, W.P.A., \& Buishand, T.A. (2003). Assessing future discharge of the river Rhine using regional climate model integrations and a hydrological model. Climate Research, 23, 233-246. https://doi.org/10.3354/cr023233

Sheffield, J., \& Wood, E. (2008). Projected changes in drought occurrence under future global warming from multi-model, multi-scenario, IPCC AR4 simulations. Climate Dynamics, 31, 79-105. https://doi.org/10.1007/s00382-007-0340-z

Skowera, B., Wojkowski, J., \& Ziernicka-Wojtaszek, A. (2016). Warunki termiczno-opadowe na obszarze województwa opolskiego w latach 1981-2010. Infrastruktura i Ekologia Terenów Wiejskich, 3(2), 919-934.

Soja, R. (2002). Hydrologiczne aspekty antropopresji w polskich Karpatach. Prace Geograficzne, 186. Warszawa: IGiPZ PAN. 
Spinoni, J., Antofie, T., Barbosa, P., Bihari, Z., Lakatos, M., Szalai, S., \& Vogt, J. (2013). An overview of drought events in the Carpathian Region in 1961-2010. Advances in Science and Research, 10, 21-32. https://doi.org/10.5194/asr-10-21-2013

Starkel, L. (1972). Charakterystyka rzeźby Polskich Karpat (i jej znaczenie dla gospodarki ludzkiej). Problemy Zagospodarowania Ziem Górskich, 10, 75-91.

Stocker, T. F., Qin, D., Plattner, G.-K., Tignor, M. M. B., Allen, S.K., Boschung, J., Nauels, A., Xia, Y., Bex, V., \& Midgley, P.M. (2013). Climate change 2013: The physical science basis. Working Group I Contribution to the Fifth Assessment Report of the Intergovernmental Panel on Climate Change, Cambridge University Press.

Tallaksen, L.M., Hisdal, H., \& Van Lanen, H.A. (2009). Space-time modelling of catchment scale drought characteristics. Journal of Hydrology, 375(3-4), 363-372.

https://doi.org/10.1016/j.jhydrol.2009.06.032

Tomaszewski, E. (2007). Pora koncentracji odpływu podziemnego w środkowej Polsce. W: Z. Michalczyk (red.) Obieg wody w środowisku naturalnym i przekształconym (s. 537-547). Lublin: UMCS.

Tomaszewski, E. (2012). Wieloletnia i sezonowa dynamika niżówek w rzekach środkowej Polski. Łódź: Wydawnictwo Uniwersytetu Łódzkiego.

Tomaszewski, E. (2018). Low-flow discharge deficits assessment, applying constant and variable low-flow threshold levels, as illustrated with the example of selected catchments in the Vistula River basin. Acta Scientiarum Polonorum Formatio Circumiectus, 18(3), 205-216.

Turc, L. (1964). Evapotranspitation potentielle mensuelle et décadaire. Son eevaluation en fontion donneés météorologiques. Polsko-Francuskie Sympozjum Gospodarki Wodnej, Warszawa: Wydawnictwo Komunikacji i Łączności.

Unrug, R. (red.). (1969). Przewodnik geologiczny po zachodnich Karpatach fliszowych. Warszawa: Wydawnictwa Geologiczne.

USGS. (2017). Dane publiczne SRTM. Pobrane z: https://srtm.csi.cgiar.org/srtmdata (06.07.2017).

Wanders, N., Wada, Y., \& Van Lanen, H.A.J. (2015). Global hydrological droughts in the 21st century under a changing hydrological regime. Earth System Dynamics, 6, 1-15.

https://doi.org/10.5194/esd-6-1-2015

Wang, G., Yang, H., Wang, L., Xu, Z., \& Xue, B. (2014). Using the SWAT model to assess impacts of land use changes on runoff generation in headwaters. Hydrological Processes, 28(3), 1032-1042. https://doi.org/10.1002/hyp.9645

Wypych, A., Ustrnul, Z., \& Schmatz, D.R. (2018). Long-term variability of air temperature and precipitation conditions in the Polish Carpathians. Journal of Mountain Science, 15(2), 237-253. https://doi.org/10.1007/s11629-017-4374-3

Yevjevich, V. (1964). An objective approach to definitions and investigations of continental hydrologic drought. Hydrology Paper, 23. Fort Collins: Colorado State University.

Zielińska, M. (1964). Metody obliczania i prognozowania niżówek w ujęciu probabilistycznym. Wiadomości Służby Hydrolologicznej i Meteorolologicznej, 58, 31-57.

Ziemońska, Z. (1973). Stosunki wodne w polskich Karpatach Zachodnich. Prace Geograficzne, 103. Warszawa: IGiPZ PAN.

Żmudzka, E. (2010). Changes in thermal conditions in the high mountain areas and contemporary warming in the central Europe. Miscellanea Geographica, 14(1), 59-70. https://doi.org/10.2478/mgrsd-2010-0006

Żytko, K., Gucik, S., \& Ślączka, A. (1973). Przewodnik po wschodnich Karpatach fliszowych. Warszawa: Wydawnictwo Geologiczne. 


\section{Summary}

Water flow in the Polish Carpathians was exemplified by long-term (1988-2017) analysis of two foothill catchments (of the Skawinka and Stobnica) and two catchments in the Beskidy Mountains (of the Soła and Osława). The work allowed for the determination of the duration of low flows and outflow deficits in relation to changes in thermal and precipitation conditions, as well as land use and land cover. In the selected catchments, the 30-year period brought a decrease in the area of arable land and an increase in the area of grassland and forest. In addition built-up areas increased by 495\% between 1990 and 2018. A greater susceptibility to the occurrence of total drought was noted for the Beskidy Mountains catchments, in which the duration of low flows and outflow deficit was greater than in the foothill catchments. At the same time, the mountain catchments proved less susceptible to the emergence of deep drought, on account of their higher levels of forest cover and levels of soil permeability. In regional terms, the durations of low flows and outflow deficits were greater in the catchments located in the eastern part of the Carpathians (those of the Stobnica and Osława), in line with this area's intensified features of a continental climate. 